\title{
Modern Trends in Dynamics and Structure of Working Capital of the Russian Economics
}

\author{
Irina Viktorovna Degtyarova ${ }^{1} \&$ Guzel Farisovna Tokareva ${ }^{1}$ \\ ${ }^{1}$ Federal state budgetary educational institution of higher professional education, 'Ufa State Aviation Technical \\ University', Republic of Bashkortostan \\ Correspondence: Irina Viktorovna Degtyarova, Federal state budgetary educational institution of higher \\ professional education, 'Ufa State Aviation Technical University', 450000, Ufa, Karl Marx Street, 12, Republic \\ of Bashkortostan. E-mail: sapfo79@mail.ru
}

\author{
Received: September 24, 2014 Accepted: March 2, 2015 Online Published: May 16, 2015 \\ doi:10.5539/ass.v11n13p61 \\ URL: http://dx.doi.org/10.5539/ass.v11n13p61
}

\begin{abstract}
In the modern context of innovational development, structural changes in manufacturing, global changes on product and stock markets, increase in influence of tax system and other factors of government regulation, quality changes take place in the whole reproduction process including working capital functioning. The present article substantiates changes in the dynamics and structure of working capital in the Russian economy and gives analysis forces affecting it. Research was carried out at the macroeconomic level on the basis of official statistics for the period of 1993-2012 about structure of working capital, current liquidity and organizations' accounts payable upon obligations published in the website of the Federal service of state statistics and also upon main indicators of market of state short-term bonds (GKO) and federal loan bonds (OFZ), indicated in the website of the Central bank of Russia.

The article substantiates changes of the working capital's structure in the Russian economics which include reduction of stocks share, increase in monetary funds and other financial assets. Much attention is given to changes in structure of financial sources forming the working capital, increase in money supply that contributes to instability of the money market.
\end{abstract}

Keywords: circulating capital, material and monetary components of the circulating capital, accounts payable, current liquidity, profitability

\section{Introduction}

\subsection{Introduce the Problem}

One of the main reasons for the economic slowdown in Russia was working capital deficiency which guaranteed continuity between production process and circulation. Many companies and whole industries have lost their own working capitals. Thus, problem of effective using of working capital attract attention of Russian scientists and practitioners. It is of topical importance to definite structure of working capital for industrial enterprises because of in this area of Economics working capital passes all stages of the production cycle and different by length of cycle.

The changes in dynamics and structure of working capital are results of transformation processes in the Russian economy, development of various forms of ownership, but also the diversity of the economic behavior of the owners and managers of enterprises. The output result of the activities of economic entities always comes down to profit and improve the financial stability that influenced by volume and structure of capital advanced in the commercial activities of the enterprises.

In the modern context of innovational development, structural shifts in manufacturing, global changes in product and stock markets, increase in influence of tax system and other factors of government regulation, quality changes take place in the whole reproduction process including circulating capital functioning. In connection with this, the need to prove modern formation and functioning laws of the circulating capital of the Russian economics arises.

The article is concerned with study of modern trends in dynamics and structure of the circulating capital (CC) of the Russian economics as one of the most important indicators of public production's efficiency. 


\subsection{Explore Importance of the Problem}

Modern conditions of innovative development, structural changes in manufacturing, global changes on product and stock markets, increase in influence of tax system and other factors of government regulation a major impact on the working capital functioning. In this regard, it is necessary to study modern trends in the forming and operation of the working capital of the Russian economy.

\subsection{Describe Relevant Scholarship}

In Russian economic literature much attention are paid to the problems of organization of the working capital and current assets (Barnholtz S. B., Boyko S. I., Bunich P. G., Bychkov P. S., Gagarina L. G., Gerasimova L. N., Ilyin S. S., Kovalev V. V., Lisitsian N. S., Rothstein L. A., Shumov N. S., etc.); these problems were reflected in the works of foreign authors, including Dixon J., Gross D., Crips D., Stephen A. Ross, Hansen L. P., Harrison J., Hein E. , Reid G., Richard S., Epstein B., etc.).

However, since the 90s of the XX century in Russian economic literature there are no special investigations devoted to forming and using of working capital at the stage of the transfer to innovation type of socio-economic development as well as the global financial and economic crisis.

In early studies which are devoted to mentioned problems, as a rule, much attention is paid to current assets as an integral part of working capital in comparison with the fixed assets having other economic nature. At the same time the amount of working capital and its advance for long periods especially in the material-intensive sectors of the economy with long production cycles closely related these economic categories that are not enough reflected in economic literature. Underestimation of this in practice leads to distortions in the use of production resources, including underutilization of production capacity or excessive stocks of material resources, which in both cases has a negative impact on production efficiency. This situation is exacerbated by insufficient attention to structure of working capital. At the same time, excessive accumulation of working capital, also as well as a lack on separate phases and stages of process of circulation negatively influences on efficiency of reproduction of working capital.

The features of reproduction of working capital in high-tech sectors have not yet been surveyed in detail. At the same time, they are in the worst conditions: their intellectual capital isn't registered, isn't estimated as a part of assets and therefore can't serve as deposit for the loan. High price of the credit makes it available only for sectors with a high speed of working capital.

An integrated approach to the analysis of modern trends in dynamics and structure of working capital in the Russian economy will help to fill the theoretical and methodological base of the research created by the Russian and foreign scientists. On this basis could be developed the concept of reproductive of management of working capital of as an organic part of the capital, providing continuity of production processes in industrial enterprises.

The key areas and results of recent studies could serve as a scientific basis for insertion of changes and additions to the federal laws, which realization will promote recovery of the Russian economy; can be used by managers and specialists from government, as well as by research organizations.

\section{Methods}

\subsection{Sampling Procedures}

Methods of data analysis and formal logic have been used for the present research. Sampling was carried out on the basis of official statistics for the period of 1993-2012 about structure of CC, current liquidity and organizations' accounts payable upon obligations published in the website of the Federal service of state statistics and also upon return on the market of state treasury bills and federal loan bonds for the period of 2002-2010, indicated in the website of the Central bank of Russia.

\subsection{Sampling Procedures}

In the Russian economy since 1940 till 1989 planning of values of working capital of the enterprises was carried out and it was considered as an essential element of management of economy within command system. Decision of the USSR Council of Ministers (About improvement working capital regulating methods in state enterprises and organizations) was adopted in 1962. On the basis of this decision working capital regulating methods for economic sectors, which set a percentage ratio of elements in its structure, were developed. There have been no significant movements in dynamics and structure of working capital of the Soviet economy.

Market reforms in Russia launched in 1994 freed businesses from (duty) under "top-down" planning. Since that time till the present moment working capital management at the enterprises is made upon the specifics of the industry as well as the macroeconomic situation in the country. Therefore 1993 had been chosen as a reference 
point for given research.

\section{Results}

\subsection{Statistics and Data Analysis}

According to understanding of classical economics, the circulating capital has always been productive assets, given the fact that it provides not only creation of a product or service in production, but also becomes a condition and factor for creation of earned value (of profit). For the circulating capital to exist, the circulation phase is needed too. In the circulation CC appears as monetary funds (proceeds, circulating assets) and leftovers. The circulating capital has thinner flow in material form than value advanced on it. Its flow is defined by boundaries of the production phase - basis point here is stock of materials, end point is finished product inventories. Simultaneous location of CC in three forms (production form, commodity form, money form) is reflected on the structure of $\mathrm{CC}$ (see the Table 1).

Table 1. Structural changes of the circulating capital in the Russian economics as whole (1993-2010), \% *

\begin{tabular}{|c|c|c|c|c|c|c|c|c|c|c|c|}
\hline & 1993 & 1995 & 2000 & 2003 & 2004 & 2005 & 2006 & 2007 & 2008 & 2009 & 2010 \\
\hline $\begin{array}{l}\text { Circulating assets, total } \\
\text { including: }\end{array}$ & 100 & 100 & 100 & 100 & 100 & 100 & 100 & 100 & 100 & 100 & 100 \\
\hline Stock, among them: & 40.7 & 40.8 & 24.9 & 23.3 & 22.8 & 23.2 & 23.6 & 23.2 & 22.4 & 21.3 & 20.6 \\
\hline $\begin{array}{l}\text { depreciable value of } \\
\text { production stock }\end{array}$ & 17.7 & 16.2 & 12.5 & 10.0 & 9.3 & 8.9 & 8.9 & 8.6 & 7.8 & 6.9 & 6.8 \\
\hline $\begin{array}{l}\text { expenses on incomplete } \\
\text { production }\end{array}$ & 5.8 & 8.4 & 5.4 & 6.2 & 6.0 & 6.1 & 6.0 & 5.7 & 5.6 & 5.3 & 4.7 \\
\hline prepaid expenses & 0.4 & 0.5 & 0.6 & 1.4 & 1.4 & 1.7 & 1.7 & 1.7 & 1.8 & 1.8 & 1.7 \\
\hline $\begin{array}{l}\text { finished products and goods } \\
\text { ready for sale }\end{array}$ & 14.0 & 11.5 & 5.2 & 5.1 & 5.4 & 5.7 & 6.2 & 6.4 & 6.7 & 6.7 & 6.6 \\
\hline goods dispatched & 0 & 0 & 1.0 & 0.5 & 0.5 & 0.6 & 0.6 & 0.6 & 0.5 & 0.5 & 0.5 \\
\hline $\begin{array}{l}\text { Monetary funds, } \\
\text { settlements and other } \\
\text { assets, among them: }\end{array}$ & 59.3 & 59.2 & 75.1 & 76.7 & 77.2 & 76.8 & 76.4 & 76.8 & 77.6 & 78.7 & 79.4 \\
\hline monetary funds & 8.6 & 4.0 & 5.5 & 6.0 & 6.4 & 7.1 & 6.9 & 6.5 & 6.7 & 7.3 & 7.5 \\
\hline $\begin{array}{l}\text { short-term financial } \\
\text { investments }\end{array}$ & 1.0 & 1.8 & 8.3 & 10.2 & 13.9 & 13.0 & 13.8 & 14.8 & 18.4 & 17.6 & 17.3 \\
\hline
\end{tabular}

*the official website of state statistics of the Russian Federation

Analysis of historical data, given in the table 1, shows that the structure of CC in the national economics cannot be considered as practical, as there is mismatch between its material and money components, i.e. parts in sphere of production and sphere of circulation. In the period of interest, prevailing share of $\mathrm{CC}$ is in money form and sphere of circulation, while its location in material form and sphere of production creates more favorable conditions for efficient use of CC. Moreover, we can observe tendency of reduction of CC participation in servicing its material part and in monetary part growth, and subsequently, reduction of its share in sphere of production and rise in sphere of circulation.

$\mathrm{CC}$ structure prevailing recently doesn't conform with recommended indices according to which the stock must be equal to $60-65 \%$ and monetary assets to $10-20 \%$, (Bocharov, 2008, p. 118). CC structure in comparison with planned economics seems irrational (Danilina, 2009; Smirnov, 2013). If in 1993 share of stocks of national economics in their total sum was equal to $40.7 \%$, then in 2010 it was only $20.6 \%$.

Changes in dynamics are results of influence of both positive and negative factors. In national economics within the period of interest significant attrition of production stocks for more than 2.5 times can be observed (from $17.7 \%$ in 1993 to $6.8 \%$ in 2010), stocks of finished products and goods for sale reduced 2 times more (from $14.0 \%$ to $6.6 \%$ ) and in-process stock from 5.8 to $4.7 \%$. Given that production stocks tightly bound to finished products and goods, and the latter in their turn are interconnected with unfinished production, then total reduction of these elements of $\mathrm{CC}$ has negative consequences on the national economics, which is reflected on decrease in industrial production rate - only in last12 years this index fell till $6.1 \%$ (from $108.7 \%$ in 2000 to 102.6 in 2012). Given the fact that volume of the produced goods affects size of unfinished production in direct 
ratio, i.e. the more production is produced under other equal conditions, the more the size of unfinished production is, subsequently, reduction of such CC elements like unfinished production, finished products and goods for sale will affect obtained final result, particularly GDP, growth rate of which significantly fell from $110.0 \%$ in 2000 to $103.4 \%$ in 2012 .

On the other hand, we can trace influence of market incentives on the mentioned tendencies too, including abandoning of central resource allocation (as it was in planned economics), development of logistics, outsourcing and introduction of free market of production goods, enterprises' wish to produce saleable goods and work with minimum of production stocks which leads to reduction of nonproductive 'production stocks' and decrease in operating expenses on their storage.

In this regard the future task is in transfer from mainly extensive management methods to mainly intensive methods which allows to increase efficiency of the circulating capital usage on a national scale.

Inefficiency of the current structure of circulating assets is characterized by high specific gravity in CC of money funds and other assets. Thus, circulating asset ratio on these points rose from $59.3 \%$ to $79.4 \%$ in the national economics within the period of interest.

At times of reduction of $\mathrm{CC}$ material form, increase of short-term financial investments can be observed. The present issue has relatively low specific gravity, but can also be characterized by high growth rate (17 times more) (from 1.0 to $17.3 \%$ ). Such sudden rise can be explained by high efficiency of speculative trading in the financial market and, first of all, the market of government short-term and federal loan bonds (see the Figure 1).

Short-term financial investments, $\%$

Rates of the market of government short-term and federal loan bonds, $\%$

Zero-coupon profitability of federal loan bonds, $\%$

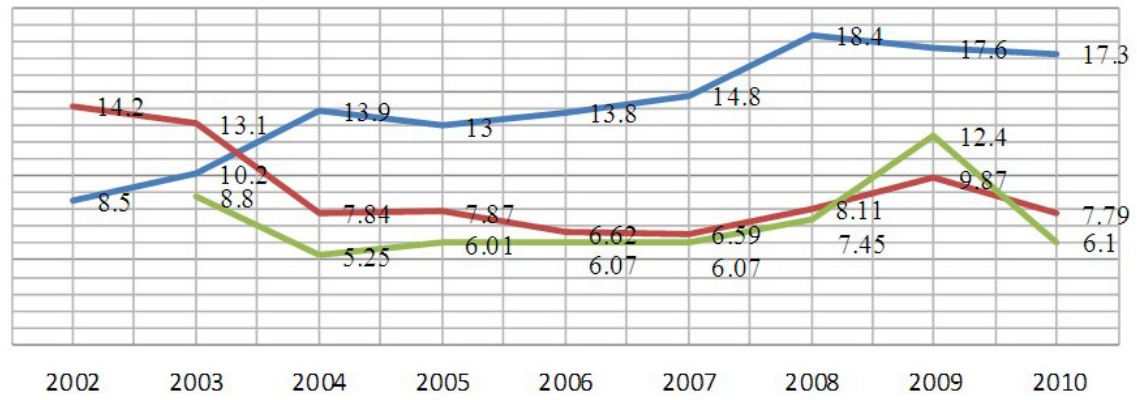

Figure 1. Short-term financial investments and profitability of the market of government short-term and federal loan bonds (the official website of the Central bank of the Russian Federation)

The given fact is confirmed by growth of financial business investments in economics in general. Thus, sum of financial investments grew 26 times more within the period from 1993 to 2012 (from 2575 RUB bn to 67724.7 RUB bn), index of short-term financial investments has been changing most - they grew 50 times more (from 1202 RUB bn to 60711.8 RUB bn), while long-term investments rose only 5 times more (from 1373 RUB bn in 1993 to 7012.9 RUB bn in 2012). As result, the very structure of financial investments faced serious changes (Yufryakov, 2011). In 1993 correlation of short-term and long-term investments was approximately equal $46,7 \%$ and $53 \%$, but serious imbalance could be observed in $2012-89.6 \%$ and $10.3 \%$.

Specific element of circulating assets is money funds from which every circulation of CC starts and with which it ends. On the basis of analysis of circulating assets' structure we can state that changes of money funds' share in their contents weren't a strongly marked tendency. Thus, within the period of interest their specific gravity in the national economics reduced from $8.6 \%$ to $7.5 \%$ in the presence of sizeable fluctuations both towards increase and reduction in terms of separate years.

\subsection{Ancillary Analyses}

In a number of major economic sectors similar changes can be observed too (see the Table 2).

Data analysis of the Table 2 shows that in 2000s the maximum specific gravity of the circulating capital in its productive form in the manufacturing industry falls at preclinical year of 2007 (33.6\%), which was preceded by stable growth of the circulating capital throughout three years. This again proves existence of correlation 
between production growth and rise of the circulating capital share in its material form (Goncharova, 2012). Alongside with this, the whole situation is characterized by urge of industrial companies to get free of the circulating capital in stock form in favor of money capital and invest part of monetary circulating assets to the market of government short-term and federal loan bonds, especially in those periods when rates of the market of government short-term bonds and zero-coupon profitability of federal loan bonds skyrocket.

Table 2. Circulating capital in major sectors of the Russian economics (2002-2010), \%*

\begin{tabular}{lccccccccccc}
\hline & 1993 & 1995 & 2000 & 2003 & 2004 & 2005 & 2006 & 2007 & 2008 & 2009 & 2010 \\
\hline $\begin{array}{l}\text { Manufacturing industry } \\
\text { Circulating assets, total }\end{array}$ & 100 & 100 & 100 & 100 & 100 & 100 & 100 & 100 & 100 & 100 & 100 \\
$\begin{array}{l}\text { Stock } \\
\text { Agricultural sector }\end{array}$ & 39.7 & 42.4 & 31.7 & 31.4 & 27.2 & 32.1 & 33.1 & 33.6 & 31.1 & 28.2 & 27.7 \\
$\begin{array}{l}\text { Circulating assets, total } \\
\text { Stock }\end{array}$ & 100 & 100 & 100 & 100 & 100 & 100 & 100 & 100 & 100 & 100 & 100 \\
$\begin{array}{l}\text { Construction industry } \\
\text { Circulating assets, total }\end{array}$ & 107.7 & 80.4 & 71.8 & 65.4 & 64.1 & 64.2 & 58.7 & 56.0 & 56.4 & 55.1 & 52.6 \\
Stock and expenses & 27.6 & 33.3 & 29.1 & 20.5 & 19.0 & 23.0 & 25.4 & 21.5 & 22.6 & 21.9 & 23.2 \\
$\begin{array}{l}\text { Transportation } \\
\text { Circulating assets, total }\end{array}$ & 100 & 100 & 100 & 100 & 100 & 100 & 100 & 100 & 100 & 100 & 100 \\
Stock & 19.9 & 25.9 & 13.9 & 9.3 & 20.0 & 19.4 & 18.1 & 15.9 & 13.8 & 12.3 & 11.1 \\
\hline
\end{tabular}

*the official website of state statistics of the Russian Federation

In the agricultural sector, in view of industry specificity, connected first of all with slower rate of capital circulation and presence of the winter period, the circulating capital share is huge (till $80.4 \%$ ). A number of authors (Popov, 2011; Sidorov, 2012; Ukhobotov, 2012) explain absence of close correlation between production growth and rise of the circulating capital share for a number of reasons: firstly, the agricultural sector of Russia significantly depends on climatic conditions, secondly, underdevelopment of market relations, existence of shadow schemes of agricultural production sales, low investments cause chronic industrial absence of money. Taking into account government grants, it's unlikely to think that the current size of the circulating capital reflects agriculture's objective need in it. Stagnation nature of modern agricultural development is accompanied first of all by reduction of productive stocks (by $25 \%$ for 9 years) which leads to disturbance of reproduction process and is not typical for the industry with seasonal nature of production.

$\mathrm{CC}$ reduction takes place slower in construction and transportation within the period of interest. Construction, unlike agricultural sector, is characterized by prevailing of financial assets where advances of customers hold a special place. Low volume of unfinished production, according to a number of researchers (Goremykin, 2010), can be explained by payment of construction-assembly work in separate stages. According to views of the authors studying economics of the construction (Buzyreva et al., 2010; Tsypin, 2005), building cycle have significantly reduced due to use of modern building materials and technologies, and margin received from resale of immovable property (particularly elite real estate in the biggest cities of the country) has increased too which let high volumes of financial resources to be attracted to the economic sector. The given events got reflected on reduction of material component of the circulating capital (from 27.6 to 23.2\%) in favor of financial assets' growth (from 72.4 to $76.8 \%$ ).

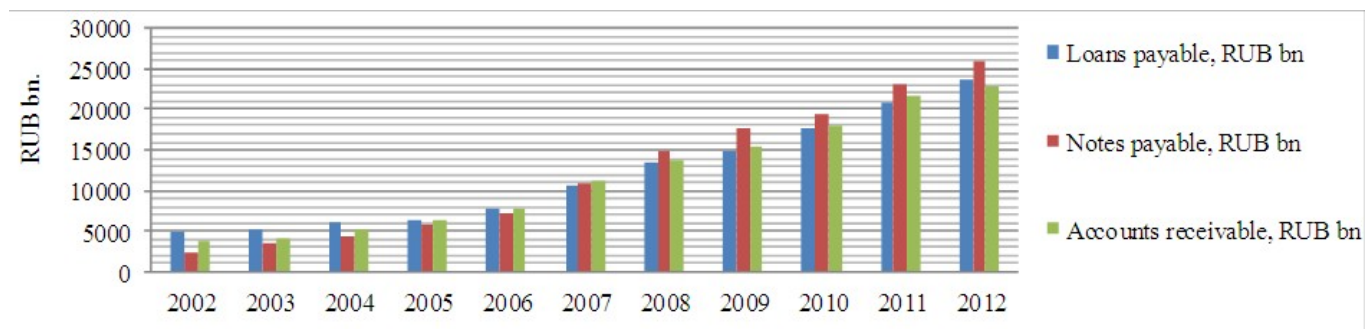

Figure 2. Business debts on economic obligations in 2002-2012, RUB bn (the official website of state statistics of the Russian Federation) 
Reduction of productive stocks affects transportation differently, where development of service system led to reduction of need in productive stocks and the circulating capital as whole. The researchers point out that in transportation sector the highest level of investments in financial assets is connected with advanced payment for transportation services (Druzhinin et al., 2011; Ryzhov, 2009; Chernikova, 2010).

The other peculiarity of $\mathrm{CC}$ formation and use is structure change of financial sources of its coverage. Loan capital has become the most used financial source of money shortfall coverage for the circulating capital formation (Degtyareva et al., 2014), which resulted in rise of companies' debts: loans payable, accounts receivable and bank loans (see the Figure 2).

As we can see from the mentioned data, significant annual buildup of loan payable can be observed in the national economics as whole within the period of interest. In the initial period (since 2002 till 2006) loan payable grows in speed going ahead of bank loans' growth that were dealt next years and that can be estimated as positive tendency in whole. But the tendency of annual buildup of loans payable against preceding years has been observed till the present time. We must consider that presence of loans payable, particularly overdue debts, shows existence of problems in mutual settlements and payment crisis in certain years. In view of this, structure of debts in the national economics cannot be called satisfactory.

Negative tendencies can also include growth of notes payable in their total debt (the Figure 2). This fact in whole certifies disadvantageous state of settlements in the national economics and their negative influence on capital's functioning. It should be noted that rise of loan capital in the structure of CC financing generates more dangerous financial risks to the company's activity - risk of financial stability decrease and solvability loss; assets formed due to loan capital provide least profit level which decreases by sum of payable lending rate in all its forms (interest on bank credit, lease rates, bond yield, bill interest for inventory credit, etc.).

Due to this, the most spread source of the circulating capital formation in modern Russian economics is loans payable (within the period of interest it increased almost 5 times more from 4832.3 to 23631.7 RUB bn). It is more available unlike bank loans, cheaper and even free of charge, since prompt payment discounts are applied very rarely, fines and sanctions for overdue payments are also used as an exceptional case (Kovalev, 2012).

It has been noted above that at times of planned economics CC structure was facing prevalence of productive stocks. We could observe a different case in planned economics too - diverting significant means of companies to overdue indebtedness (the Figure 3).

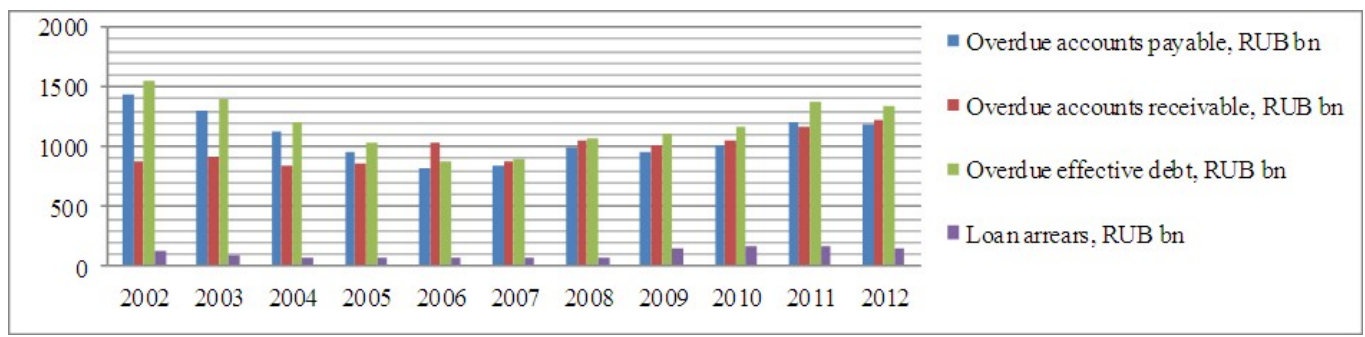

Figure 3. Dynamics of companies' overdue indebtedness in economics for 2002-2012, RUB bn (the official website of state statistics of the Russian Federation)

Analysis of $\mathrm{CC}$ structure allows to draw the conclusion that the very growth of non-payments deform $\mathrm{CC}$ structure and also structure of financial sources of its covering which influences negatively on economics as whole. Observed rise of overdue receivables since 2007 is definitely a negative moment. Yes, on the one hand, receivables growth can indicate rise of company's prospective incomings and liquidity, but from the other hand, it offers immobilization, i.e. diverting own working capital off economic turnover. Naturally this process is accompanied by collateral losses in companies' incomings, relative importance of which is more significant, as inflation rate is getting higher.

Availability of receivables in huge amounts which under shortage of own circulating assets or their full absence is covered against loan payable, deforms their structure; leads to disproportion of their service of the circulation's material and value spheres, including the spheres of production and circulation. All this causes failures in the circulation process, non-payments and negatively influences on efficiency of the circulating capital functioning.

Own circulating assets or registered capital must be the most important one among reproduction sources in the part aimed at constant participation in CC formation. But their Figure nowadays is very low. Ratio of own circulating assets' use in 1993 was equal to $11.5 \%$, in 2010 was equal to $-14.1 \%$, i.e. shortage of own sources for 
CC formation can be observed in the national economics that in its turn contributes to continuous business failures (29.1\% from total number of companies are unprofitable companies in 2012).

In the absence of enough volume of own circulating capital, credit resources are classical form of CC loan part formation. Correlation between own and loan parts of the circulating capital is reflected on indices of current liquidity, circulating assets coverage ratios and equity-assets ratios. Change of these indices shows certain progress of not only companies in whole, but first of all of the circulating capital movement too (the Table 3).

Table 3. Current liquidity, circulating assets coverage ratios and equity-assets ratios (2002-2010), \%*

\begin{tabular}{llll}
\hline year & $\begin{array}{l}\text { Ratio of } \\
\text { current liquidity }\end{array}$ & own circulating assets coverage & equity-assets \\
Manufacturing industry & & 35.2 \\
\hline 1993 y. & 130.1 & 12.8 & 56.7 \\
2002 y. & 110.0 & -5.8 & 44.9 \\
2003 y & 117.4 & -4.8 & 45.5 \\
2004 y. & 125.7 & -0.4 & 44.1 \\
2005 y. & 139.7 & -3.4 & 46.4 \\
2006 y. & 150.2 & 1.3 & 45.2 \\
2007 y. & 139.0 & -4.8 & 40.8 \\
2008 y. & 140.5 & -9.4 & 41.2 \\
2009 y. & 138.4 & -12.3 & 42.6 \\
2010 y. & 146.1 & -8.2 & \\
\hline
\end{tabular}

*the official website of state statistics of the Russian Federation

Manufacturing industry as whole is characterized by increase of current liquidity and own circulating assets coverage ratio. The highest (preclinical) level can be observed in 2006 (150.2 and 1.3), then obvious falling trend in 2009 (138.4 and -12.3), then growth (146.1 and -8.2) in 2010 again. In preclinical and critical periods condition of own circulating capital coverage significantly got worse. Indices for these years indicate, that most businesses lost their own circulating assets totally, which negatively affects literate economic activity in the modern context. It is worth noting that in the state-planned command economy the structure of circulating assets formation sources wasn't much important, since all businesses belonged to the unified owner represented by the government. In market economy loss of own circulating assets significantly increases bankruptcy risks.

Decrease in own circulating capital share of the Russian industrial businesses indicates that the most circulating capital has been formed due to loan sources. In our opinion, these factors quite accurately indicate negative aspects of modern Russian economics and subsequently the circulating capital flow. This conclusion is confirmed by solvency ratio that takes into account the total size of equity capital too. Throughout the years of 2002-2008 significant decrease was observed, but already after 2008, when liquidity loss risk arose, financial mangers set a course for crisis intervention, which later resulted in growth of equity capital share in the structure of industrial companies' assets.

Situation with current liquidity indices, own circulating assets coverage shows acute shortage of the circulating capital both in manufacture and the Russian economics as whole one more. The circulating capital is the most important capital in general process of expanded production. Though within the years of interest, we can observe the trend of gradual decline in its share: CC specific gravity in the national economics in 2013 was equal to $2 \%$ compared to $12 \%$ of 1980 (the official website of state statistics of the Russian Federation).

Lack of the circulating capital in the real economic sector can be explained by high rate of bank loans and high taxes (Bagautdinova \& Tokareva, 2013; Timofeeva, 2012). Both of them are factors influencing on formation of the circulating capital, but their influence shouldn't be overestimated. Reasons for high rates of bank loans and high taxes can be explained in its turn by general state of economics, state budget, inflation, etc. (Degtyareva et al., 2014). That's why main reasons for the circulating capital loss come from the real sector of economics (both in production and non-production spheres).

Low economic efficiency of the industrial production of Russia, reduction of own accumulation sources don't allow to solve the issue about the circulating capital gains at the expense of own resources. The crisis of 2008 
aggravated these trends even more, but even after 5 years it's impossible to speak about start of new cycle of economic progress - product and assets profitability continues to decline both in manufacturing and in economics as whole (see the Table4).

Table 4. Product profitability in economics and manufacturing industry of Russia (2005-2012), \%

\begin{tabular}{llll}
\hline & 2005 year & 2011 year & 2012 year \\
\hline Profitability of sold goods and services: total in economics & 13.5 & 9.6 & 8.6 \\
Manufacturing industry & 15.3 & 13.2 & 10.7 \\
Profitability of assets: total in economics & 8.8 & 6.5 & 6.1 \\
Manufacturing industry & 11.9 & 8.4 & 8.1 \\
\hline
\end{tabular}

*the official website of state statistics of the Russian Federation

\section{Discussion}

Inflation rate is crucial for functioning of the circulating capital. High inflation (over $10 \%$ per year) depreciates future incomings of companies, moderate one allows to foresee its influence on the circulating assets index with adequate accuracy.

$\mathrm{CC}$ formation at the expense of credits has contributed to money funds rise in the Russian economics, which according to monetarist theory causes inflation. Within the period of interest, money supply (M2) grew from 1612.6 RUB bn to 15267.7 RUB bn, i.e. growth was observed for 9 times (the official website of state statistics of the Russian Federation) which was really accompanied by inflation. Though, analysis of only monetary sources of inflation doesn't explain the Russian phenomenon which doesn't stay within the monetarist theory to the full extent. The fact that in 2008 the inflation started speeding up (from 9.7 to $12.4 \%$ ) at times of decline in conservation and economic growth retardation, and on the contrary, some inflation retardation (from 10.1 to 9.7) observed in 2007, was happening in the background of monetary fund's growth (6033.1 to 8970.7 RUB bn) indicates, that the main source of inflation is not only money factors but also growth of production costs and high level of monopolism. In market economy the usage of energy, raw materials and others to a large extent depends on market prices on these components of production means, and one of problems here is pricing monopolization from natural monopolies. Appreciation of natural resources at the expense of monopoly rent also makes investments in $\mathrm{CC}$ of manufacturing industry ineffective, which becomes the reason of the circulating capital loss and production profitability decline, as was indicated above (see the Table 4). Due to this, tough budgetary policy, government assistance in transformation of savings into business investments is necessary, and money supply growth won't lead to price rise.

New important tendency of the circulating capital functioning in modern Russian economics is changes in CC structure connected with growth of specific cost on labor force and science (Yakovleva, 2014). General payroll fund in 2000-2012 grew 10 times more (from 27.76 to 307.8 RUB bn), and it's not connected with growth of employment in economics - annual employment in economics rose within the same period only by 5\% (from 64327 to 67968 people). In the structure of production costs labor costs in 2000 made $1 / 7$, in 2012 they made already $1 / 6$. Growth of specific costs connected with R \& D is characterized by high rate - only within the period of 2005 till 2012 this index increased 2 times more.

\section{Conclusion}

Summarizing study of the changes happening in the circulating capital functioning in modern Russian economics, we can state the following:

1) In modern Russian economics trend of the circulating capital share reduction both in the national economics as whole and its leading industry of manufacturing have developed. A real problem of the circulating capital loss exists within the whole reproduction process.

2) Trend of the circulating capital share reduction can be confirmed during analysis with a breakdown into industries. Production stocks and expenses' decrease in transportation, absence of reforming in agriculture lead to deep critical situation, production stock reduction, deceleration of circulation speed and capital turnover in general, the circulating capital in particular; change of the circulating capital structure caused by rapid development of the Russian property market can be observed in construction sphere.

3) In the circulating capital structure of the Russian economics the prevailing share of CC is in money form and 
the sphere of circulation, we can observe trend of CC participation reduction in service of its material part and in growth of its money part, subsequently, reduction of its share in the production sphere and increase in the circulation sphere.

4) In the background of CC material form reduction, increase in short-term financial investments takes place. Within the period since 2005 till 2009 the circulating capital was under specific pressure of the financial market due to profitability differences: rates of the market of government short-term and federal loan bonds continuously grew in the background of production profitability reduction in manufacturing industry, which also gave occasion to reduction of natural and material parts of $\mathrm{CC}$ in favor of the monetary one.

5) Significant growth of share of CC formation loan sources and also high level of non-payments in the Russian economics deform the current structure of $\mathrm{CC}$ which negatively influences on the whole economics.

6) The circulating capital loss is accompanied by growth of money supply which contributes to instability of the money market. Analysis of the Russian economics shows that the main source of inflation are not only monetary factors but also growth of production costs and high level of monopolism. That's why measures of credit and loan policy must be complemented by systemic support of the circulating capital reproduction in the real sector of economy.

\section{Acknowledgments}

The research was carried out with financial support of the Russian Foundation for Basic Research, project № 13-06-00680A 'Reproduction of the circulating capital of industrial businesses under modern conditions of innovation development and ways of its efficiency enhancement'.

\section{References}

Bagautdinova, I. V., \& Tokareva, G. F. (2013). Problems of crediting as basis of the circulating capital reproduction under conditions of Russia's accession to WTO membership. Russian entrepreneurship, 23.

Bocharov, V. V. (2010). Corporate finance. S.-Petersburg: 'Piter' printing house.

Buzyreva, V. V., \& Suvorova, A. P. (2010). Construction economics: Work book. Moskva, M: 'Academiya' printing house.

Chernikova, L. I. (2010). Research methodology of modern capital transformations: Financial aspect: Author's abstract. Doctoral dissertation. Cherkizovo, Russia.

Danilina, E. I. (2009). Production program as basis of the circulating capital's reproduction. Russian entrepreneurship, 4(1).

Degtyareva, I. V., Marina, A. V., \& Shalina, O. I. (2014). Structure formation of the circulating capital financing sources of the Russian businesses: Regalia and development thrusts. Vestnik USATU, 18(2), 63.

Druzhinin, P. V., Ponomarev, A. Ya., \& Kabanov, A. N. (2011). Modernization of systems of transport logistics, service and urban planning regional outsourcing. Technical and technological problems of service system, $4(18)$.

Goncharova, E. A. (2012). Circulating funds and circulating assets management: Work book. S.-Petersburg.: Printing house of Saint-Petersburg State Economics and Finance University.

Goremykin, V. A. (2010). Real estate economics. Moskva, M: 'Yurayt' printing house.

Kovalev, V. V. (2012). Business assets management: Practical work guide. Moskva, M: 'Prospekt' printing house.

Popov, N. A. (2010). Economics of agriculture. Moskva, M: 'Magistr' printing house.

Ryzhov, I. V. (2009). Analysis of typical directions of investment attraction to domestic businesses. Finance and credit, 4.

Sidorova, D. V. (2012). Peculiarities of reproduction process in agriculture: author's abstract. Doctoral dissertation. University of Stavropol, Russia.

Smirnov, S. V. (2013). Dynamics of industrial production in USSR and Russia. Part II. Crisis and cycles, the years of 1861-2012. Economic issues, 7.

The official website of state statistics of the Russian Federation. Retrieved from http://www.gks.ru

The official website of the Central bank of the Russian Federation. Retrieved from http://cbr.ru/

Timofeeva, Z. A. (2012). On modernization of the Russian banking system. Money and credit, 9. 
Tsypin, P. E. (2005). Analysis of investment projects' efficiency in construction. M.: Moscow State University of Railway Engineering.

Ukhobotov, V. V. (2012). Reproduction of labor resources of agriculture: Author's abstract. Doctoral dissertation. Moscow, Russia.

Yakovleva, T. N. (2014). Theoretical and methodological peculiarities in research of the circulating capital functioning. Humanitarian, social and economic sciences, 4.

Yufryakov, Yu. (2011). Prospective of capital attraction by companies of the second and third tiers: Opportunities, conditions, tools. Equity market, 9(414).

\section{Copyrights}

Copyright for this article is retained by the author(s), with first publication rights granted to the journal.

This is an open-access article distributed under the terms and conditions of the Creative Commons Attribution license (http://creativecommons.org/licenses/by/3.0/). 